\title{
Physiological and Structural Abnormalities of Coconut Plants (Cocos nucifera L.) at Different Stages of Growth and Plantation Sites under Low Temperature Condition in Bangladesh
}

\author{
M. Mamunur Rashid ${ }^{1}$, M. Shamim Hasan ${ }^{1}$, M. H. Rahman ${ }^{2}$, \\ Abu Noman Faruq Ahmmed ${ }^{3}$ and K. M. Khalequzzaman ${ }^{4}$ \\ ${ }^{1}$ Department of Plant Pathology, ${ }^{2}$ Department of Horticulture, Hajee Mohammad Danesh Science and \\ Technology University, Dinajpur-5200, Bangladesh; ${ }^{3}$ Department of Plant Pathology, Sher-e-Bangla \\ Agricultural University, Dhaka, Bangladesh; ${ }^{4}$ Division of Plant Pathology, Spice Research Centre, \\ Bangladesh Agricultural Research Institute, Shibganj, Bogra, Bangladesh \\ *Corresponding author and Email: shamimhstu@ gmail.com
}

Received: 5 October $2015 \quad$ Accepted: 12 December 2015

\begin{abstract}
Physiological and structural changes of coconut plants at different growth stages and plantation sites under low temperature conditions was investigated during 1997-98, 2002-03, 2005-06 and 2009-10 in the northern region of Bangladesh. Three growth stages viz. $<7,7-15$ and $>15$ years and three locations viz. road side, near pond and near drain were selected for this study. Leaf area damage with characteristics lesions categorized into mildly damaged, moderately damaged and dead plants. Age and planting site revealed very significant differences. The highest percent of dead (49.84-58.49 \%), moderately damaged (37.20-46.21\%) and mildly damaged plants (65.70-74.79\%) were found in road side, while the highest percent of dead plants (39.93-45.58\%), moderately $(20.18-26.68 \%)$ and mildly damaged plants (69.46-70.37\%) were found in above 15 years old plants. The lowest percent dead of plants $(20.82,18.27$ and $19.55 \%)$ were found in pond side and $(11.74,12.53$ and $13.31 \%)$ in the $7-15$ years old plants. The mean temperature, sunshine hours and total precipitations remained below 16.88 ${ }^{\circ} \mathrm{C}, 10.25$ hours and $11.7 \mathrm{~cm}$, respectively during 1997-98, 2002-03 and 2009-10. The highest amount of potassium $(0.57 \mathrm{me} / 100 \mathrm{~g}$ soil $)$ was found in pond side soil, whereas the lowest amount of potassium $(0.11 \mathrm{me} / 100 \mathrm{~g}$ soil $)$ was found in road side soil. It has been concluded that low temperature (below $16.88{ }^{\circ} \mathrm{C}$ ), mean precipitation $11.7 \mathrm{~cm}$ and amount of potassium $0.11 \mathrm{me} / 100 \mathrm{~g}$ in soil were responsible for severe damage of the coconut plants in the study area.
\end{abstract}

Keywords: Coconut, low temperature, age, damage, abnormalities

\section{Introduction}

Coconut plant (Cocos nucifera L.) is mainly crop of coastal region of Bangladesh. It is called "the tree of life" or "tree of heaven" because of the endless medical benefit from it as direct products or bio-products providing income to a good number of populations in this country. Coconut can be lucratively cultivated up to $600 \mathrm{~m}$ above sea level and it requires warm conditions for successful growth. Coconut plant showed optimum growth at mean annual temperature of $27{ }^{\circ} \mathrm{C}$ and growth is reduced at temperature below $21{ }^{\circ} \mathrm{C}$ (Thampan, 1984). Some seasonal deviation is tolerated with good growth where mean summer temperature remains between 28 - 
$37{ }^{\circ} \mathrm{C}$ and survive as long as winter temperature is above $4-12{ }^{\circ} \mathrm{C}$. Successful growth requires a minimum average temperature of $22{ }^{\circ} \mathrm{C}$ and an annual rainfall of $89-127 \mathrm{~cm}$ or more. Coconut palms are highly susceptible to cold weather. The trees showed injury by cold when the temperature falls below $0{ }^{\circ} \mathrm{C}$ with desiccated foliage as the primary symptom.

Coconut requires full sunlight and is tolerant to wind. Severe freezes can also result in dead of the bud. Coconut is not suitable for areas where freezing temperatures regularly prevail. These may show leaf injury at temperature below $1{ }^{\circ} \mathrm{C}$, defoliate at $-1{ }^{\circ} \mathrm{C}$, and die at $-3{ }^{\circ} \mathrm{C}$. One night of freezing weather can set the growth of a coconut back about 6 months (Broschat, 2010). It is difficult for coconut plants to be established in dry climates and cannot grow there without frequent irrigation. Well-distributed rainfall of $100-225 \mathrm{~cm} /$ year is ideal for coconut plants (Menon and Pandalai, 1960). The coconut thrives on sandy soils and is highly tolerant to salinity. Irrigation is essential to prevent excessive water stress and leaf desiccation. After a cold spell, even those trees which appear undamaged should be sprayed with a micronutrient or fungicides. Low temperature, particularly below $15{ }^{\circ} \mathrm{C}$ results in cold injuries to the coconut, resulting in severe leaf blotch and abnormal fruit development. Warm and humid conditions are desirable for its cultivation in coastal region of Bangladesh with humidity of $80-90 \%$. The relative humidity below $50 \%$ affects opening of the stomata. Long prevalence of cool weather especially in January-February imposes excessive stress on coconut which makes their roots incapable of providing nutrients to their buds. Plants are thus vulnerable to diseases, which may cause bud collapse in warmer, spring weather. The low temperature in winter of northern region of Bangladesh during 1997-98 caused first time cold injury to coconut. The winter was the coldest and darkest for more than one month of the last sixty years (Rashid, 2000). Again a severe loss was found in the coldest winter of 2002-2003 (Anon., 2003).
Potash has important and specific functions apart from those, which it jointly performs in association with phosphorus for the growth and development of coconut plants. It regulates the water economy of the plant and is indispensable for the rational utilization of limited water supplies for the production of the highest possible yields. It enables the plants to withstand drought. Potash is known to help root development, enabling the palm to take up more nutrients from the soil. Since potash is particularly necessary for the formation of sugar, fat, and fibrous material, the coconut palm may be expected to have a high requirement of potash.

An experiment was therefore, undertaken to study the effect of low temperature on damage of coconut plants in northern region of Bangladesh during the last severe cold prevailing seasons.

\section{Materials and Methods}

The study was carried out at Dinajpur district (northern region) of Bangladesh during the period of 1997-98, 2002-03, 2005-06 and 200910. The average temperatures in December, January and February for each study period were recorded and average mean values were computed (Table 5). Established plants were selected for injury severity assessment based on water sources at different sites, age of plants and presence of potassium in soil. In total, seventy five plants of three age categories $(<7,7-15$ and $>15$ years old) were selected for evaluation, with 25 plants at pond side, 25 plants at near the drain and 25 plants at road side. The plantation sites were selected based on the availability of water at the root zone of coconut plants.

Data on severities of injury were recorded once in the month of April of each period where each plant was evaluated for single replication. The data were recorded on injury severities categorized into dead (top death or $>75 \%$ leaf area damage), moderately ( $>25 \%$ to $<75 \%$ leaf area damage) and mildly damaged plants $(<25 \%$ leaf area damage). 
Soil samples were collected from ground of each plant to evaluate exchangeable potassium. Exchangeable potassium was determined by flame photometer after digesting the samples with normal ammonium acetate (Pratt, 1965). Briefly, the soil sample was extracted with a one molar ammonium acetate solution at $\mathrm{pH}=7.00$. The soil-solution slurry was shaken for 2 hours, and the solution was separated from the solid by centrifugation. The addition of ammonium in excess to the soil displaced the rapid exchangeable potassium and potassium cations from the exchange sites of the soil particles. Finally, potassium in this solution was determined with a flame photometer. All the recorded data on different parameters were subjected to statistical analysis following Duncan's Multiple Range Test.

\section{Results and Discussion}

Effect of low temperature on the damage of coconut plants at different ages and planting sites during 1997-98, 2002-03, 2005-06 and 2009-10 are presented in the Tables (1-4). Data revealed considerable effect in all the cold periods. The highest numbers of dead, moderately and mildly damaged plants were found in road side plants which were followed by plants of above 15 years, but the injury was lower in 7-15 years old plants planted near pond sides for the subsequent three cold periods. The highest percent of dead (39.93-45.58 \%), moderately (20.18-26.68\%) and mildly damaged plants (69.46-70.37\%) were found in above 15-year old plants. Furthermore, the highest percent of dead (49.84$58.49 \%)$, moderately $(37.20-46.21 \%)$ and mildly damaged plants (65.70-74.79\%) were recorded in road side plants during 1997-98, 2002-03 and 2009-10. The findings indicate that, younger coconut plants have more adaptively to the cold weather than the older plants. Moreover, availability of the water and potassium at rhyzosphere of coconut plants also help to reduce the adverse effects of low temperature in coconut plants.
The mean average temperature of December, January and February remained 15.84, 15.73 and $16.88^{\circ} \mathrm{C}$, respectively. Sunshine hours remained below 10.25 hours through 1997-98, 2002-03 and 2009-10, whereas the mean average temperature and sunshine hours remained 19.47 ${ }^{\circ} \mathrm{C}$ and 10.45 hours in these three months for the period of 2005-06 (Table 5). The average mean temperature in December, January and February during 1997-98 was the lowest in the north-west region of Bangladesh over last 60 years (Rashid, 2000). A total rainfall in these three months was below $11.7 \mathrm{~cm}$ during 1997-98, 2002-2003 and 2009-2010. Conversely, there was $14.6 \mathrm{~cm}$ rainfall in the year of 2005-06. This finding is in partial agreement with Thampan (1984) who reported that for vigorous growth and yield, a mean annual temperature of $27{ }^{\circ} \mathrm{C}$ is the best. The palm fails to flourish in areas where the mean temperature falls below $21{ }^{\circ} \mathrm{C}$ and also where the temperature fluctuations are considerable. Consequently, for vigorous growth and significantly higher quality yield the average mean temperature in December, January and February should remain above $16.88{ }^{\circ} \mathrm{C}$ in this locality.

The leaf symptoms were found in three distinct types: the red blotch, the yellow spot (potassium deficiency) and the grey spots (Pestalotia infection). Red blotch appeared as injury to the structure of leaf and fruit caused by cold weather (Broschat, 2010) whereas, the other two symptoms prevailed normally and included in this study as predisposing the injury. The fruit symptoms were nearly similar to leaf symptoms but severe necrosis was mostly found in the month of April. The effect on severities of cold injury on coconut plants appeared in epidemic form especially in this region due to recent changes in climate, especially over the last 14 years. This was very common injury of coconut in northern part of Bangladesh. The first visible symptom of the injury was pinhead necrotic yellowish-brown spots on the leaflet which rapidly become oval in shape and encircled by yellow margin. With the decrease of temperature with shorter sunshine hours and foggy weather, 
the spots rapidly coalesce, resulting in form of necrosis. The leaf blades showed burnt or blighted appearance causes severe foliage necrosis followed by whole crown dead. Eventually, the leaves of the plant turn completely blighted and most of them remain hanged on the trunk. Symptoms were also found on petiole, costa, fruit and trunk.

Reddish-burn like lesion with depressed centre was found on the surface of the trunk. In crosssection of bottom stem, the cortex regions mostly surrounding the vascular bundles region showed reddish brown lesion. This observation is in agreement with Larcher and Winter (1981) and Broschat (2010). The blight extends to the bud and kills it leaving only the trunk standing. The fruits are also affected in the same way and fall off. Some mature fruits had little amount of water, but was non-edible with bad odor. At the end of the session, the plants started steadily normal growth with increasing temperature except the dead plants. The palm prefers an equable climate and does not tolerate extremes of temperature. Several field studies revealed that the nutrient and water balance of coconut with $150 \mathrm{~m}^{2}$ leaf area transpires 30-120 L water/day depending on the atmospheric evaporative demand and the soil water level (Nair et al., 1993). Low temperature reduces the soil moisture and humidity in atmosphere, increases transpiration diminishing supply of water and nutrient in the plant. Changes in leaf water status of coconut reflected in changes of the levels of chlorophyll and potash. As a result, the plants become weak and lose it water retention capacity, increase the concentration of free amino nitrogen, epicuticular wax and total soluble sugars.

The shortage of water and increase in the concentration of cellular substances cause malfunctioning of the enzyme system, finally resulting in malignant of the cell. Broschat (2010) reported that necrosis caused by chilling temperatures in coconut palms was significantly less in palms fertilized routinely with an $8 \mathrm{~N}$ $2 \mathrm{P}_{2} \mathrm{O}_{5}-12 \mathrm{~K}_{2} \mathrm{O}-4 \mathrm{Mg}$ plus micronutrients irrigated palm fertilizer than in unfertilized palms. Several studies have also demonstrated that proper fertilization could improve cold hardiness of coconut palms.

In general, the level of free amino acids, epicuticutilar wax and total soluble sugars are higher in rainfed palms as compared to irrigated palms (Nair et al., 1993). An insoluble organic pigment produces black-amber and dark brown colors by deposition in the cuticle of cell that is formed by oxidation of amino acid tyrosine in the presence of specific melanogenic enzymes. The study revealed that cold temperature damaged and infected severely in above 15 and below 7 years old coconut plants under road side but they could protect them from cold damage near drain. This result is partially supported by Meerow (2005) who reported that planting palm in areas protected by buildings or tree canopies can increase their chances of survival during cold weather. Inclusion of proper water supply led to water status in plant cells suggesting that inhibition of deposing the soluble contents might be a professional means of management for cold damage. It may be concluded that cold temperature severely damaged and injured the coconut plants of below seven and above 15 years of age with temperature below $16.88{ }^{\circ} \mathrm{C}$. This may be due to impact of low temperature susceptibility of the young and older plants.

The highest amount of potassium $(0.50-0.57$ $\mathrm{me} / 100 \mathrm{~g}$ soil) was found in the pond side, whereas the lowest $(0.11-0.14 \mathrm{me} / 100 \mathrm{~g}$ soil) was recorded near the road side rhizosphere soil during the study (Table 6). Lower amount of potassium in the road side resulted the highest level of damage of coconut plants. The main role of potassium is to provide the appropriate ionic environment for metabolic processes in the cytosol, and as such functions as a regulator of various processes including growth regulation. Plants require potassium ions $\left(\mathrm{K}^{+}\right)$for protein synthesis and for the opening and closing of stomata, which is regulated by proton pumps to make surrounding guard cells either turgid or flaccid. Potassium also functions in other 
physiological processes such as photosynthesis, activation of some enzymes, phloem solute transport of photoassimilates into source organs, and maintenance of cation:anion balance in the cytosol and vacuole (Leigh and Wyn Jones, 1984).

Table 1. Effect of low temperature on the damage of coconut plants at different age of plant and planting site during 1997-98

\begin{tabular}{lcccc}
\hline Treatments & & $\begin{array}{c}\text { Dead plants } \\
(\%)\end{array}$ & $\begin{array}{c}\text { Moderately damaged } \\
\text { plants }(\%)\end{array}$ & $\begin{array}{c}\text { Mildly infected plants } \\
(\%)\end{array}$ \\
\hline \multirow{3}{*}{ Age of plants } & > 15 years & $45.58 \mathrm{~b}$ & $26.68 \mathrm{c}$ & $68.55 \mathrm{~b}$ \\
& 7-15 years & $20.82 \mathrm{~d}$ & $15.36 \mathrm{f}$ & $30.86 \mathrm{e}$ \\
\multirow{3}{*}{ Planting site } & < 7 years & $26.68 \mathrm{c}$ & $22.39 \mathrm{e}$ & $38.62 \mathrm{c}$ \\
& Road side & $58.49 \mathrm{a}$ & $46.21 \mathrm{a}$ & $74.79 \mathrm{a}$ \\
& Near Pond & $13.31 \mathrm{f}$ & $22.50 \mathrm{~d}$ & $33.67 \mathrm{~d}$ \\
& Near Drain & $18.69 \mathrm{e}$ & $36.29 \mathrm{~b}$ & $28.17 \mathrm{ef}$ \\
\hline $\mathrm{CV}(\%)$ & - & 7.38 & 4.98 & 8.33 \\
\hline
\end{tabular}

In a column, figures having same letter (s) do not differ statistically at 5\% level of significance by DMRT.

Table 2. Effect of low temperature on the damage of coconut plants at different age of plant and planting site during 2002-03

\begin{tabular}{llccc}
\hline Treatments & & $\begin{array}{c}\text { Dead plants } \\
(\%)\end{array}$ & $\begin{array}{c}\text { Moderately damaged } \\
\text { plants }(\%)\end{array}$ & $\begin{array}{c}\text { Mildly infected plants } \\
(\%)\end{array}$ \\
\hline \multirow{3}{*}{ Age of plants } & > 15 years & $39.93 \mathrm{~b}$ & $20.18 \mathrm{~d}$ & $70.37 \mathrm{a}$ \\
& 7-15 years & $18.27 \mathrm{~d}$ & $12.29 \mathrm{f}$ & $27.28 \mathrm{e}$ \\
& < 7 years & $27.27 \mathrm{c}$ & $18.12 \mathrm{e}$ & $28.37 \mathrm{~d}$ \\
& Road side & $49.84 \mathrm{a}$ & $37.20 \mathrm{a}$ & $65.70 \mathrm{~b}$ \\
& Near Pond & $11.74 \mathrm{f}$ & $20.37 \mathrm{c}$ & $30.65 \mathrm{c}$ \\
& Near Drain & $15.43 \mathrm{ef}$ & $27.22 \mathrm{~b}$ & $22.39 \mathrm{f}$ \\
\hline $\mathrm{CV}(\%)$ & - & 5.80 & 8.45 & 6.79 \\
\hline
\end{tabular}

In a column, figures having same letter (s) do not differ statistically at 5\% level of significance by DMRT.

Table 3. Effect of low temperature on the damage of coconut plants at different age of plant and planting site during 2005-06

\begin{tabular}{lcccc}
\hline Treatments & $\begin{array}{c}\text { Dead plants } \\
(\%)\end{array}$ & $\begin{array}{c}\text { Moderately damaged } \\
\text { plants }(\%)\end{array}$ & $\begin{array}{c}\text { Mildly infected plants } \\
(\%)\end{array}$ \\
\hline \multirow{3}{*}{ Age of plants } & > 15 years & $2.00 \mathrm{a}$ & $4.00 \mathrm{a}$ & $6.00 \mathrm{ab}$ \\
& 7-15 years & $1.00 \mathrm{c}$ & $3.00 \mathrm{~b}$ & $5.00 \mathrm{~b}$ \\
\multirow{3}{*}{ Planting site } & < 7 years & $1.50 \mathrm{~b}$ & $4.00 \mathrm{a}$ & $5.50 \mathrm{ab}$ \\
& Road side & $1.50 \mathrm{~b}$ & $2.00 \mathrm{c}$ & $3.50 \mathrm{c}$ \\
& Near Pond & $1.00 \mathrm{c}$ & $3.00 \mathrm{~b}$ & $5.00 \mathrm{~b}$ \\
& Near Drain & $2.00 \mathrm{a}$ & $4.00 \mathrm{a}$ & $6.50 \mathrm{a}$ \\
\hline $\mathrm{CV} \%$ & & 15.15 & 10.26 & 12.66 \\
\hline
\end{tabular}

In a column, figures having same letter (s) do not differ statistically at 5\% level of significance by DMRT. 
Table 4. Effect of low temperature on the damage of coconut plants at different age of plant and planting site during 2009-10

\begin{tabular}{lcccc}
\hline Treatments & Dead plants (\%) & $\begin{array}{c}\text { Moderately } \\
\text { damaged plants }(\%)\end{array}$ & $\begin{array}{c}\text { Mildly infected } \\
\text { plants }(\%)\end{array}$ \\
\hline \multirow{3}{*}{ Age of plants } & $>15$ years & $42.76 \mathrm{~b}$ & $23.44 \mathrm{c}$ & $69.46 \mathrm{~b}$ \\
& 7-15 years & $19.55 \mathrm{~d}$ & $13.83 \mathrm{f}$ & $29.62 \mathrm{e}$ \\
& $<7$ years & $26.98 \mathrm{c}$ & $20.26 \mathrm{e}$ & $32.95 \mathrm{c}$ \\
Planting site & Road side & $54.17 \mathrm{a}$ & $41.71 \mathrm{a}$ & $70.25 \mathrm{a}$ \\
& Near Pond & $12.53 \mathrm{f}$ & $21.44 \mathrm{~d}$ & $32.16 \mathrm{~d}$ \\
& Near Drain & $17.06 \mathrm{e}$ & $31.76 \mathrm{~b}$ & $25.28 \mathrm{f}$ \\
\hline $\mathrm{CV}(\%)$ & - & 5.40 & 9.68 & 6.39 \\
\hline
\end{tabular}

In a column, figures having same letter (s) do not differ statistically at 5\% level of significance by DMRT.

Table 5. Average monthly weather data of the years 1997-98, 2002-2003, 2005-2006 and 2009-2010

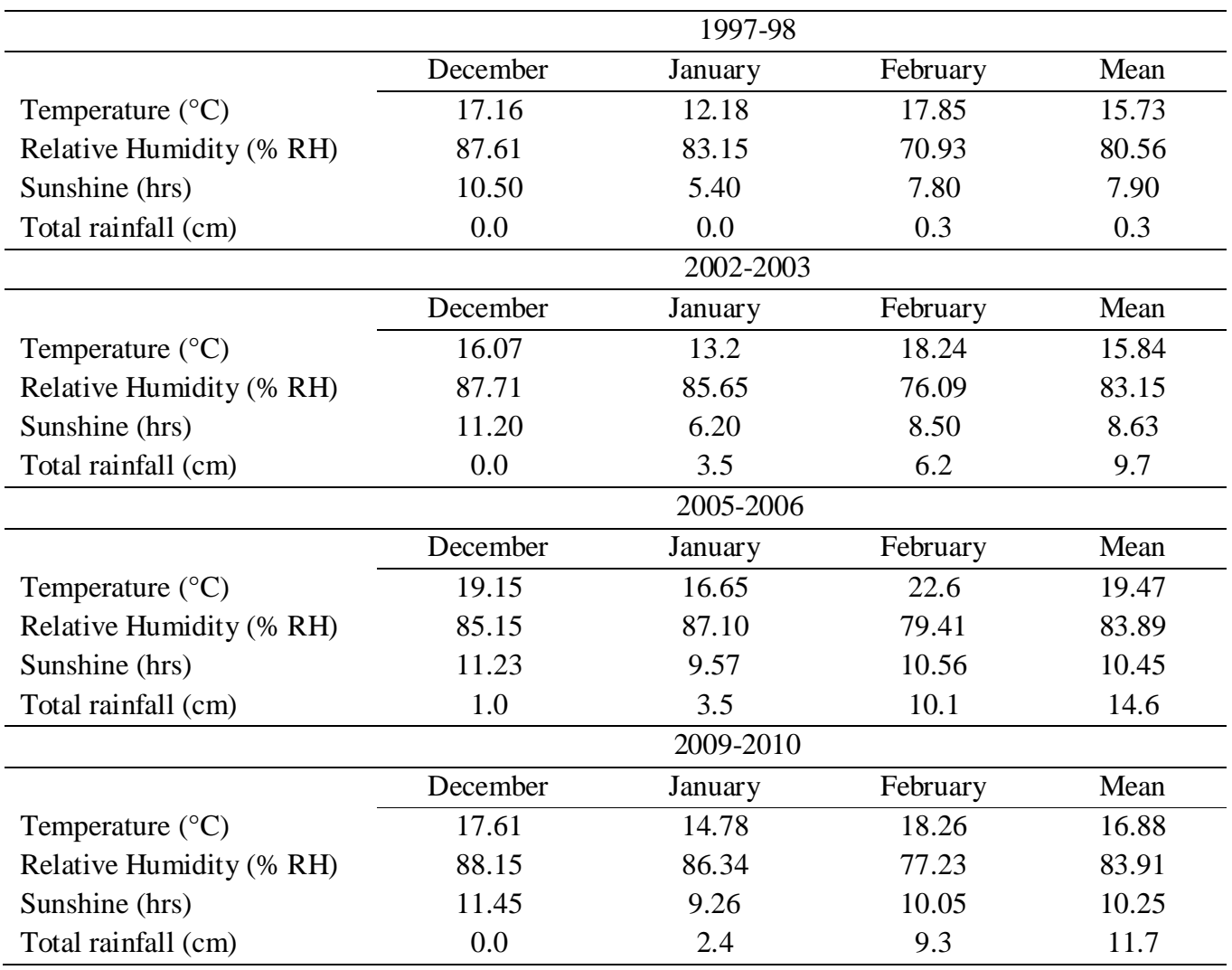


Table 6. Total amount of $\mathrm{K}^{+}$in soil of different locations during the study period of 1988, 2003, 2006 and 2010

\begin{tabular}{lllll}
\hline Treatments & \multicolumn{4}{c}{ Amount of $\mathrm{K}^{+}$me/100gm soil } \\
\cline { 2 - 5 } & 1988 & 2003 & 2006 & 2010 \\
\hline Road side & $0.14 \mathrm{c}$ & $0.12 \mathrm{c}$ & $0.11 \mathrm{c}$ & $0.13 \mathrm{c}$ \\
Pond side & $0.57 \mathrm{a}$ & $0.52 \mathrm{a}$ & $0.50 \mathrm{a}$ & $0.55 \mathrm{a}$ \\
Near Drain & $0.39 \mathrm{~b}$ & $0.33 \mathrm{~b}$ & $0.32 \mathrm{~b}$ & $0.35 \mathrm{~b}$ \\
\hline CV\% & 13.45 & 11.78 & 12.90 & 17.44 \\
\hline
\end{tabular}

In a column, figures having same letter (s) do not differ statistically at 5\% level of significance by DMRT.

\section{Conclusions}

This research was carried out to investigate the cold effect on the physiological and structural changes of coconut plant during four cold prevailing seasons in northern region of Bangladesh. This study revealed that the highest percentage of dead, moderately damaged and mildly damaged plants were found in above 15 years old plants those were grown in road side. On the other hand, the lowest percentage of dead, moderately damaged and mildly damaged plants were found in pond side and in 7-15 years old plants. It is concluded that cold temperature below $16.88^{\circ} \mathrm{C}$, average mean precipitation $11.7 \mathrm{~cm}$ and amount of potassium $0.11 \mathrm{me} / 100 \mathrm{~g}$ in soil severely damaged the coconut plants in this locality.

\section{References}

Anonymous, 2003. Uttranchale narikel gacher morok samassha (Bangla). The Daily Dinkal, Reported by Niaj Iqbal Pavel, HSTU, Dated December 31, 2003.

Broschat, T. K. 2010. Fertilization improves cold tolerance in coconut palm. HortTechnology, 20:852-855.

Larcher, W. and Winter, A. 1981. Frost susceptibility of palms: Experimental data and their interpretation. Principes, 25:143-152.
Leigh, R. A. and Wyn Jones, R. G. 1984. A Hypothesis Relating Critical Potassium Concentrations for Growth to the Distribution and Functions of This Ion in the Plant Cell. New Phytologist, 97:1-13.

Meerow, A. W. 2005. Betrock's cold hardy palms. Betrock Info. Systems, Florida, 31 p.

Menon, K. P. V. and Pandalai, K. M. 1960. The Coconut Palm: a Monograph, Indian Central Coconut Committee, Ernakulam, 261-265 pp.

Nair, M. K., Khan, H. H., Gopalasundaram, P. and Bhaskara Rao, E. V. V. 1993. Advances in coconut research and development. Oxford \& IBH Publishing Co. Pvt. Ltd. New Delhi-110001, 758 p.

Pratt, P. F. 1965. Potassium. In 'Methods of soil analysis, Part 2: chemical and microbiological properties'. (Ed. Black CA), American Society of Agronomy: Madison, Wisconsin, 1023-1031 pp.

Rashid, M. M. 2000. A Guidebook of Plant Pathology, Published by Shahnaz Begum, Partitporal, Shariakandi, Bogra, Bangladesh.

Thampan, P. K. 1984. Hand Book on Coconut Palm. Oxford \& Publishing Co. New Delhi 110002, 140-141 pp. 